J. Clin. Chem. Clin. Biochem.

Vol. 20, 1982, pp. 151-156

\title{
Fluoroimmunoassay of Digoxin in Serum
}

By Mohammad H. H. Al-Hakiem, R. D. Nargessi, M. Pourfarzaneh, G. W. White, D. S. Smith and Alison J. Hodgkinson

Department of Chemical Pathology, St. Bartholomew's Hospital, London, U.K.

(Received June 10/November 23, 1981)

Summary: A heterogeneous (solid-phase separation) fluoroimmunoassay for digoxin in serum was developed employing antibodies coupled to magnetisable cellulose/iron oxide particles and a fluorescein-labelled digoxin derivative as tracer. Intrinsic fluorophores and other potentially interfering components of serum samples were reliably and completely removed at the separation and wash steps of the assay procedure which were facilitated by magnetic sedimentation. In order to attain adequate sensitivity (detection limit $0.2 \mu \mathrm{g} / \mathrm{l}(0.26 \mathrm{nmol} / \mathrm{l})$ serum digoxin), a sample volume of $500 \mu \mathrm{l}$ was necessary. Assay results for patients' specimens correlated well with those obtained using established charcoal-separation $(r=0.96)$ and magnetisable solid-phase $(r=0.95)$ radioimmunoassays. The feasibility of a "stat" adaptation of the fluoroimmunoassay that involved only two standards $(0.5$ and $4 \mu \mathrm{g} / 1$ digoxin) was demonstrated. The stat method would be suitable for the assay of urgent or single specimens.

\section{Fluoroimmunassay für Digoxin im Serum}

Zusammenfassung: Ein heterogener Fluoroimmunassay mit Festphasentrennung für Digoxin im Serum wurde entwickelt. Dabei wurden an magnetisierbare Cellulose/Eisenoxid-Partikel gekuppelte Antikörper und ein Fluoresceinmarkiertes Digoxinderivat als Tracer verwendet. Im Serum enthaltene Fluorophore und andere möglicherweise störende Bestandteile wurden zuverlässig und vollständig bei dẹn Trenn- und Waschschritten des Bestimmungsverfahrens entfernt, erleichtert durch die magnetischè Sedimentation. Um adäquate Empfindlichkeit (Nachweisgrenze für Digoxin 0,2 $\mu \mathrm{g} / 1$ (0,26 nmol/1) Serum) zu erreichen, war ein Probenvolumen von $500 \mu \mathrm{l}$ erforderlich.

Die Ergebnisse des Assay für Patientenproben korrelierten gut mit denen von Radioimmunassays mit der bewährten Trennung durch Charcoal $(r=0,96)$ oder magnetisierbare Festphasen $(r \equiv 0,95)$. Die Durchführbarkeit einer "Stat"Adaptation des Fluoroimmunassay mit nur zwei Standards von 0,5 und $4 \mu \mathrm{g} / 1$ Digoxin wird gezeigt. Die "Stat"Methode wird für Notfall- oder Einzelproben als geeignet angesehen.

\section{Introduction}

Digoxin is the most widely used cardiac glycoside in the treatment of congestive heart failure and certain disturbances of cardiac rhythm (1). Dosage must be carefully adjusted to achieve optimum therapeutic effects while avoiding toxicity. The value of monitoring of digoxin levels in serum (2-4) is widely accepted, although it has been pointed out that the usefulness of such measurements in the diagnosis of drug-related toxicity has not been conclusively proven (5). Radioimmunoassays (RIA) employing ${ }^{3} \mathrm{H}$-labelled digoxin $(2,4,6)$ or a ${ }^{125}$ I-labelled digoxin derivative (6-9) as tracer are most commonly used. The latter have many advantages including their high sensitivity (low sample volume requirement) and the convenience of gamma-radiation counting, but
${ }^{125}$ I-labelled materials have limited shelf-life. In addition, there is significant legislative or emotive bias against the use of radioisotopes in some countries.

Homogeneous $(6,7,10,11)$ and heterogeneous (11-13) enzyme-immunoassays (EIA) for digoxin have been developed and shown to correlate well with RIA $(6,7,11,12)$. However, the measurement of enzyme activity as part of an immunoassay may require extra reagent-addition steps or manipulation to start or stop reaction (11-13), critical timing or temperature control $(6,7,12)$, and relatively long incubation times (between 30 and $60 \mathrm{~min}$ for the digoxin assays).

Fluoroimmunoassay (FIA) techniques have the advantage that fluorescence may be measured simply and rapidly. 
This report describes an FIA for serum digoxin that employs antibodies coupled to magnetisable solidphase particles and a fluorescein-labelled digoxin derivative as tracer. The "sequential addition" procedure (14), in which the antibody reagent is first incubated with the sample and then separately with the tracer, was adopted.

\section{Materials and Methods}

\section{Reagents}

Digoxin, digoxigenin, lethyl-3-(3-dimethylaminopropyl)-carbodiimide hydrochloride, $\mathrm{N}$-hydroxysuccinimide, and spironolactone were obtained from Sigma, Poole, Dorset, U.K.; digoxigenin monodigitoxoside, digoxigenin bis-digitoxoside, and dihydrodigoxin from Boehringer Mannheim, Mannheim, F.R.G.; carboxymethoxylamine hemihydrochloride from Aldrich, Gillingham, Dorset, U.K.; sodium metaperiodate from BDH, Poole, Dorset, U.K.; canrenone and potassium canrenoate from Searle, High Wycombe, Buckinghamshire, U.K.; bovine albumin (fraction V) from Armour, Eastbourne, Sussex, U.K.; silica-gel thin-layer chromatography sheets (DC Alufolien Kieselgel $60 \mathrm{~F}_{254}$ ) from Merck, Darmstadt, F.R.G.; and magnetisable cellulose/iron oxide particles from Technia Diagnostics, London ECI, U.K.

\section{Digoxin tracer}

Either digoxin or digoxigenin bis-digitoxoside was used as starting material, with identical procedures throughout.

\section{Dialdehyde derivative}

Digoxin or digoxigenin bis-digitoxoside $(50 \mathrm{mg}$ ) was dissolved in a mixture of $3 \mathrm{ml}$ of methanol and $1 \mathrm{ml}$ of chloroform. To the stirred solution was added dropwise $500 \mu \mathrm{l}$ of $10 \mathrm{~g} / \mathrm{l}$ aqueous sodium metaperiodate. Stirring was continued for $45 \mathrm{~min}$, then the reaction mixture was evaporated to dryness under a stream of nitrogen. Chloroform $(3 \mathrm{ml})$ was added to the residue and shaken thoroughly. The chloroform extract was separated from the inorganic solids, $100 \mathrm{mg}$ of anhydrous magnesium sulphate added, and the mixture stood for $1 \mathrm{~h}$. The chloroform layer was again separated from the solids and evaporated to dryness under nitrogen. The product was dissolved in ethanol to $25 \mathrm{~g} / \mathrm{l}$. Thinlayer chromatography with the solvent system chloroform/ methanol $\left(9+1\right.$ by volume) showed one component at $R_{f}$ 0.50 (detected by spraying with methanol/concentrated sulphuric acid $(9+1$ by volume) and warming briefly to develop a grey-brown colour).

\section{Di-(O-carboxymethyl)oxime derivative}

Sodium acetate $(30 \mathrm{mg})$ and carboxymethoxylamine hemihydrochloride $(35 \mathrm{mg}$ ) were dissolved in $150 \mu \mathrm{l}$ of water in a $5 \mathrm{ml}$ round-bottomed flask. Dialdehyde solution $(1 \mathrm{ml})$ was added and the reaction mixture refluxed on a boiling water bath for $1 \mathrm{~h}$. The course of reaction was followed by thin-layer chromatography using chloroform/acetone/glacial acetic acid $(7+2+1$ by volume). A single major product appeared at $R_{f} 0.16$ (detected with methanol/sulphuric acid as described above). The reaction mixture was reduced to a small volume under a stream of nitrogen, diluted with $1 \mathrm{ml}$ of water, then extracted twice with $2 \mathrm{ml}$ of ethyl acetate. The organic extracts were combined and dried over anhydrous magnesium sulphate. The ethyl acetate layer was separated from the solids and evaporated to dryness under nitrogen. The product was dissolved in dimethyl formamide to $10 \mathrm{~g} / \mathrm{l}$.

\section{Fluoresceinthiocarbamyl ethylenediamine}

Prepared as described previously (15).
Coupling of di-(O-carboxymethyl)oxime derivative to fluoresceinthiocarbamyl ethylenediamine

1-Ethyl-3-(3-dimethylaminopropyl)carbodiimide hydrochloride $(9.5 \mathrm{mg})$ and $\mathrm{N}$-hydroxysuccinimide $(0.5 \mathrm{mg})$ were dissolved in $1 \mathrm{ml}$ of dimethylformamide. Di-(O-carboxymethyl)oxime solution $(400 \mu \mathrm{l})$ was added and the reaction mixture stirred for $1 \mathrm{~h}$. To the resulting active ester solution was added dropwise $500 \mu \mathrm{l}$ of a $4 \mathrm{~g} / 1$ solution of fluoresceinthiocarbamyl ethylenediamine in dimethylformamide. After stirring for a further $20 \mathrm{~min}$, the reaction mixture was applied to silica-gel sheets $(250 \mu \mathrm{l}$ per sheet) which were developed with chloroform/methanoly ammonia $(40+30+5$ by volume) to separate three yellowörange products (designated $\mathrm{A}, \mathrm{B}$, and $\mathrm{C}$ ) with $\mathrm{R}_{\mathrm{f}}$ values 0.76 , 0.50 , and 0.40 , respectively. (Fluoresceinthiocarbamyl ethylenediamine had $\mathbf{R}_{\mathbf{f}} 0.05$ in this system.) The area of each product was scraped from the sheets, the scrapings eluted with $1 \mathrm{ml}$ of methanol per sheet, and the eluates stored in the dark at $4^{\circ} \mathrm{C}$.

The concentration of each product was estimated by dilution in sodium bicarbonate buffer ( $50 \mathrm{mmol} / \mathrm{l}, \mathrm{pH} \mathrm{9.0)}$ and measurement of absorbance at $\mathbf{4 9 2} \mathrm{nm}$ due to the fluorescein group. A molar lineic absorbance of $87.8 \mathrm{~m}^{2} \cdot$ mol $^{-1}$

$\left(8.78 \times 10^{4} 1 \cdot \mathrm{mol}^{-1} \cdot \mathrm{cm}^{-1}\right)$ was assumed $(15)$.

\section{Anti-digoxin magnetisable solid-phase}

Sheep anti-digoxin serum, raised against an immunogen prepared by linking 3-0-succinyl digoxigenin to bovine albumin by the mixed-anhydride procedure (16), wass obtained from Technia Diagnostics. Following established methods (15), whole antiserum $(50 \mu \mathrm{l})$ mixed with normal sheep serum $(950 \mu \mathrm{l})$ was coupled to magnetisable particles $(1 \mathrm{~g})$ that had been activated with cyanogen bromide. The product was suspended to $50 \mathrm{~g} / 1$ in diluent buffer and stored at $4^{\circ} \mathrm{C}$.

\section{Fluoroimmunoassày standards}

A solution of digoxin in ethanol $(250 \mathrm{mg} / \mathrm{l})$ was diluted in pooled normal human serum. Standards were stored at $=20^{\circ} \mathrm{C}$.

\section{Patients' specimens}

Serum specimens were taken at random from those submitted for digoxin assay to the Routine Laboratory, Department of Chemical Pathology, St. Bartholomew's Hospital, London EC1, U.K. (Plasma specimens were not suitable for assay by FIA because of a tendency to aggregate the solid-phase particles).

\section{Radioim munoassay procedures}

Digoxin levels in patients' specimens were determined in the Hospital laboratory by a charcoal-separation RIA employing ${ }^{125} \mathrm{I}$-labelled digoxin. The specimens were also assayed using mànetisable solid-phase RIA kits with ${ }^{125}$ I-tracer (Technia Diagnostics), which were used according to the manufacturer's instructions.

\section{Fluoroimmunoassay procedures}

\section{Diluent buffer}

Sodium borate buffer ( $200 \mathrm{mmol} / 1, \mathrm{pH} 9.5)$ containing $1 \mathrm{~g} / 1$ bovine albumin and $1 \mathrm{~g} / 1$ sodium azide.

\section{Wash buffer}

Sodium borate buffer ( $20 \mathrm{mmol} / \mathrm{l}, \mathrm{pH} 9.5$ ) containing $1 \mathrm{~g} / 1$ bovine albumin and $1 \mathrm{~g} / \mathrm{l}$ sodium azide.

\section{Test tubes}

Disposable polystyrene test tubes $(5.5 \times 12 \mathrm{~mm}$, No. 55.484) from Walter Sarstedt, Ĺeicester, Leics., U.K.

\section{Magnet}

Multi-polar ferrite block magnet with flat surface approx. $150 \times 200 \mathrm{~mm}$ from Mạnet Applications, London EC1, U.K. 


\section{Fluorimeter}

Perkin-Elmer Model 1000 fluorimeter (Perkin-Elmer, Beaconsfield, Bucks., U.K.) equipped with filters and modified for fluorimetry with disposable test tubes as described previously (14).

\section{Assay protocol}

All operations were performed at room temperature, in duplicate. Serum samples $(500 \mu \mathrm{l})$ were dispensed into test tubes. To each tube was added $100 \mu \mathrm{l}$ of anti-digoxin solid-phase suspension $(12 \mathrm{~g} / 1$ in diluent buffer). The tubes were vortexed and incubated for $20 \mathrm{~min}$ with a vortex after $10 \mathrm{~min}$ to prevent excessive gravitational settling of the solid-phase particles. The rack containing the tubes was placed on the magnet and the solid phase allowed to sediment magnetically over about $5 \mathrm{~min}$, then the supernatants were aspirated to waste. Wash buffer $(1.5 \mathrm{ml})$ was added, the tubes vortexed, and the solid phase again sedimented on the magnet and the supernatants aspirated to waste. To each tube was added $100 \mu l$ of digoxin tracer ( $33 \mathrm{nmol} / \mathrm{l}$ in diluent buffer). The tubes were vortexed and incubated for $20 \mathrm{~min}$ with a vortex after $10 \mathrm{~min}$. Wash buffer $(1.5 \mathrm{ml})$ was added, the tubes vortexed, and the solid phase sedimented on the magnet. The fluorescence of the supernatants was measured by placing each test tube directly in the fluorimeter.

\section{Results}

\section{Characterisation of digoxin tracer}

Fluorescent tracer products $A, B$, and $C$ were assessed by measurement of immunoreactivity using excess antidigoxin solid phase. Values of 55,70 , and $40 \%$, respectively, were obtained for tracers prepared from either digoxin or digoxigenin bis-digitoxoside. Typical concentrations of product solutions in methanol were 15,60 , and $45 \mu \mathrm{mol} / 1$, respectively. Product B was accordingly chosen for use in the FIA. No attempt was made to characterise further the various tracer products.

The results described below were obtained with a tracer prepared from digoxigenin bis-digitoxoside. However, tracer prepared by labelling digoxin behaved identically in the FIA.

\section{Assay range and detectability of digoxin}

The FIA covered the clinically important therapeutic and toxic concentration ranges (2-4) for digoxin (fig. 1). The minimal detectable concentration (17) of digoxin in serum at the $95 \%$ confidence level was 0.2 $\mu \mathrm{g} / 1(0.26 \mathrm{nmol} / \mathrm{l})$. The minimal detectable dose (17) was $0.1 \mathrm{ng}(0.13 \mathrm{pmol})$ of digoxin per tube.

\section{Precision}

Within-assay precision was assessed by measuring each of three serum specimens 10 times in duplicate, giving mean results $1.1,2.2$, and $3.1 \mu \mathrm{g} / 1$, with coefficient of variation (CV) of $9.6,4.5$, and $4.2 \%$, respectively. Assay of the same specimens in duplicate on each of 10 different days gave between-assay CV results of $12.6,6.6$, and $4.2 \%$, respectively.

\section{Recovery}

Digoxin was added at different levels to each of two specimens of normal human serum. Analytical recovery of $1 \mu \mathrm{g} / 1$ added digoxin was 90.5 and $107.5 \%$ and that of $2.5 \mu \mathrm{g} / 1$ added digoxin was 92 and $102 \%$.

\section{Specificity}

Cross-reactivities of various substances in the digoxin FIA were determined by the method of Abraham (18) in which the amount of digoxin required to cause $50 \%$ displacement of tracer from antibody is expressed as a percentage of the amount of cross-reactant required to produce the same effect. The digoxin metabolites digoxigenin bis-digitoxoside, digoxigenin mono-digitoxoside, digoxigenin, and dihydrodigoxin crossreacted to $100,100,90$, and $12 \%$, respectively, and the related drugs lanatoside $\mathrm{C}$, digitoxin, gitoxin, and ouabain to $96,3.4,2.0$, and $0.03 \%$, respectively. No detectable interference at a serum level of $1 \mathrm{~g} / \mathrm{l}$ was found with spironolactone, but its metabolites canrenone and canrenoate cross-reacted to 1.2 and $0.06 \%$, respectively. No detectable cross-reaction at the $1 \mathrm{~g} / 1$ level was found with amiodarone, cholesterol, cortisol, disopyramide, oestriol, lidocaine, procainamide, progesterone, propranolol, quinidine, or testosterone.

\section{Correlation with radioim munoassay methods}

Results for the assay of 47 patients' specimens by the FIA (y) and by the charcoal-separation RIA ( $x$ ) were related by the regression line $y=0.98 \times$ (calculated assuming the two methods to have equal precision

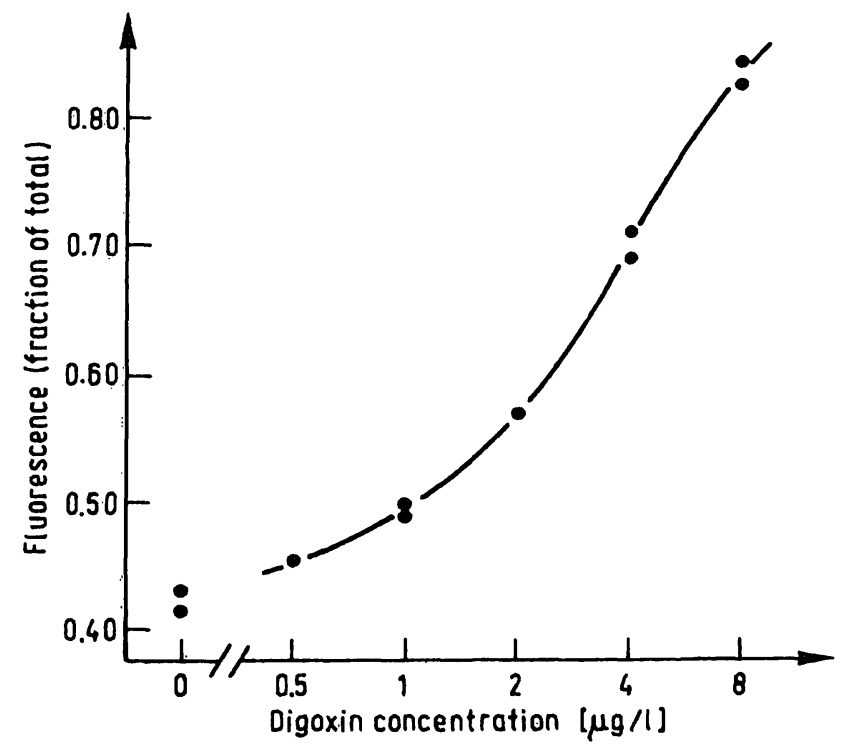

Fig. 1. Standard curve for magnetisable solid-phase fluoroimmunoassay of digoxin in serum (logarithmic concentration scale). 
characteristics (19)), with a correlation coefficient ( $r$ ) of 0.96 (fig. 2). Assay of 49 specimens by the FIA (y) and by the magnetisable solid-phase RIA ( $x$ ) yielded a line $y=0.98 x-0.1$, with $r=0.95$ (fig. 3). For c.Jmparison, the correlation between the established magnetisable solid-phase $(y)$ and charcoal-separation (x) RIA methods was given by $y=0.99 x+0.1$, with $r=0.94$ (46 specimens).

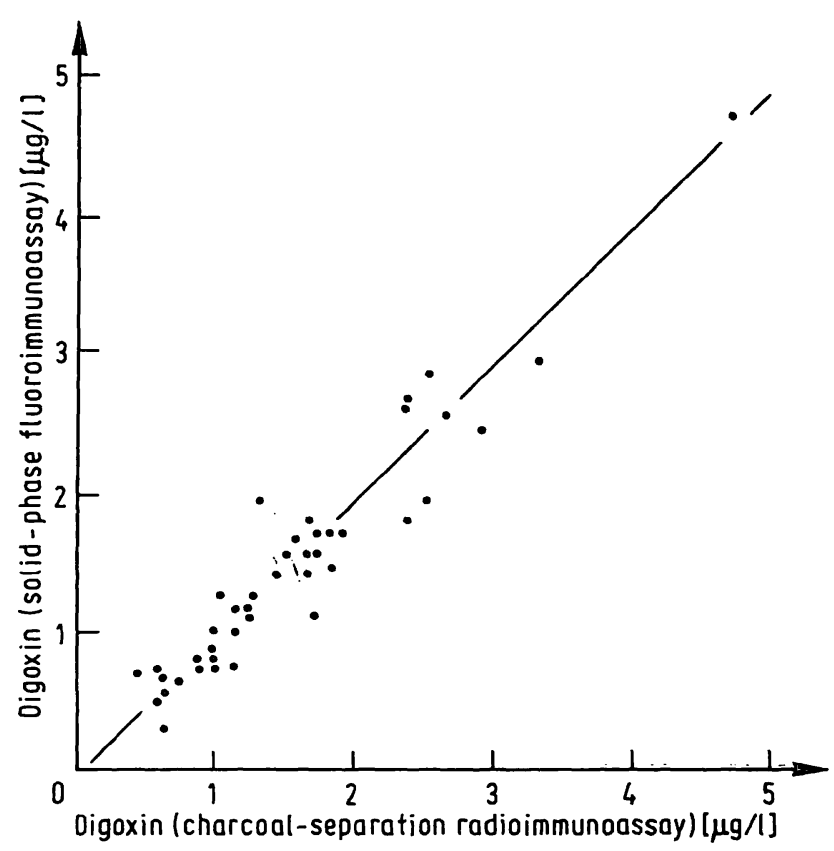

Fig. 2. Correlation between digoxin levels in patients' serum specimens determined by magnetisable solid-phase fluoroimmunoassay and by charcoal-separation radioimmunoassay, showing the regression line calculated assuming the two methods to have equal precision characteristics (19).

\section{"Stat" assay procedure}

When plotted with a linear concentration scale, the FIA standard curve showed extensive linearisation (fig. 4) which was consistently reproducible between digoxin levels of 0.5 and $4 \mu \mathrm{g} / 1$. A stat assay procedure was devised in which only two standards with these concentrations were employed and the standard curve was constructed by drawing a straight line between the corresponding points. Results for the assay of 48 patients' specimens calculated by the stat FIA method $(y)$ and by the normal FIA procedure with full standard curve $(x)$ were related by the regression line $\mathrm{y}=1.03 \mathrm{x}$, with $\mathrm{r}=0.998$.

\section{Stability of fluoroimmunoassay reagents}

Digoxin tracer preparations stored in methanol showed no change in properties over at least one and a half years, and anti-digoxin solid phase and digoxin serum standards were stable for at least two years.

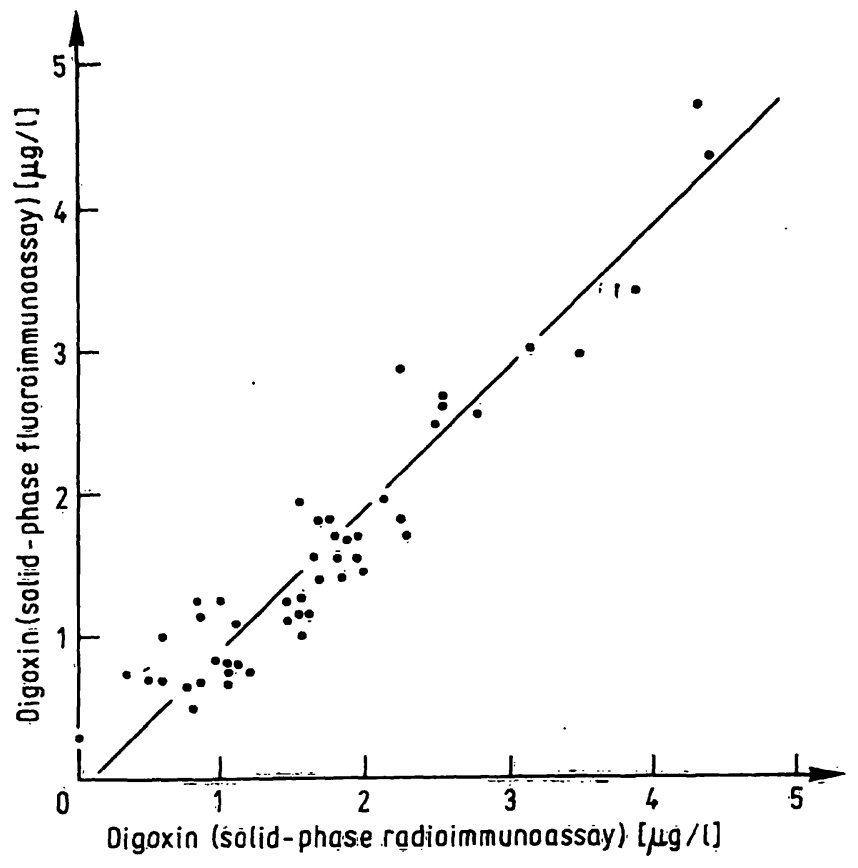

Fig. 3. Correlation between digoxin levels in patients' sérum specimens determined by magnetisable solid-phase fluoroimmunoassay and by magnetisable solid phase radioimmunoassay; showing the regression line calculated assuming the two methods to have equal precision characteristics (19).

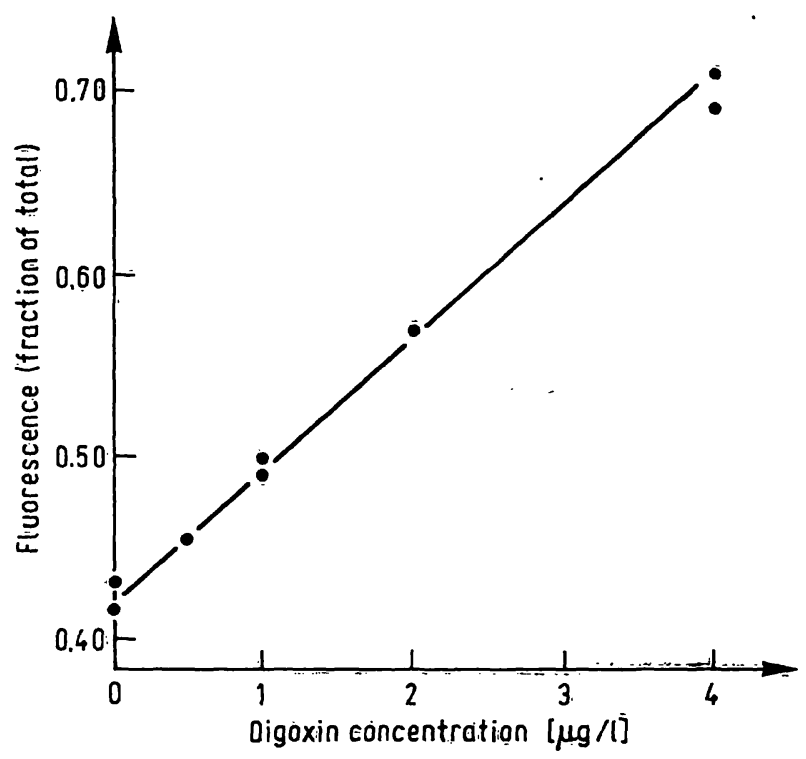

Fig. 4. Standard curve for magnetisable sölid-phase fluoroimmunoassay of digoxin in serum (linear concentration scale).

\section{Discussion}

A clinically useful digoxin assay should cover the commonly encountered therapeutic and toxic concentrations which lie $(2-4)$ in the range 0.5 to $5 \mu \mathrm{g} / 1(0.6$ to $6 \mathrm{nmol} / \mathrm{l})$. Such drug levels are easily determined by RIA employing ${ }^{125}$ I-tracer (6-9). However, it is apparent that this concentration range represents the practical limit of homogeneous ËIA, since for digoxin 
assay a sample volume of $200 \mu \mathrm{l}$ and an incubation period of $30 \mathrm{~min}$ are required $(6,7,10)$ to achieve a detection limit of $0.64 \mathrm{nmol} / \mathrm{l}(11)$, and sample pretreatment with strong alkali $(6,11)$ is necessary to prevent interference by endogenous serum constituents such as certain dehydrogenases (11). In heterogeneous EIA (11-13), sample interferences are removed in a separation step; one such assay, which has a detection limit of $0.4 \mathrm{nmol} / 1$ digoxin $(11,12)$, requires $100 \mu \mathrm{l}$ of sample and a $60 \mathrm{~min}$ incubation period for quantitation of antibody-bound enzyme-labelled digoxin (12).

As compared with the determination of enzyme activity, the measurement of fluorescence is rapid and simple; in FIA studies in this laboratory, fluorescence readings are routinely taken in five seconds using the signal-averaging facility of the Perkin-Elmer instrument. As previously demonstrated (14), fluorescence of supernatants above sedimented solid phase may conveniently be determined directly in disposable polystyrene assay tubes. In the digoxin FIA, the use of a heterogeneous assay technique enables the reliable and complete removal of serum fluorophores and other potentially interfering components at the aspiration stages, while the separation steps are facilitated by magnetic sedimentation. A general property of the sequential addition procedure adopted in this work is that tracer and sample are never in contact, and therefore non-specific serum binding interferences are entirely obviated.

It was found that a sample volume of $500 \mu \mathrm{l}$ was necessary to attain acceptable sensitivity in the FIA (detection limit $0.26 \mathrm{nmol} / \mathrm{l}$ serum digoxin). Under the fluorimetric conditions used, the background signal (consisting of fluorescent and scattered light from the wash buffer and the test tubes) amounted to about $10 \%$ of the total tracer signal, and it was judged that further significant improvement of assay sensitivity by dilution of the tracer reagent (and the solid-phase antibody) was not feasible. Curry et al. (20) have described a solid-phase FIA for triiodothyronine that employs the fluorescein-labelled hormone as tracer, requires a sample volume of $100 \mu \mathrm{l}$, and has a detection limit of $0.3 \mathrm{nmol} / \mathrm{l}$. Together with the present results, this suggests that FIA employing antigen labelled with a single fluorophore and with quantitation of this tracer by conventional fluorimetry may be generally suitable for assay of serum analytes down to concentrations of a few nanomoles per litre. Further sensitivity improvement in FIA might require, for example, the application of multi-fluorophore-labelling techniques $(21-24)$.
The term "stat" is usually applied to simplified or speeded test procedures that are suitable for assay of urgent or single specimens. Stat adaptations of digoxin RIA methods $(8,9)$ have included reduction in the number of calibrators so that the standard curve is plotted with three points only. Emergency modifications of homogeneous (6) and heterogeneous (12) digoxin EIA involving only two serum standards have been proposed. A stat FIA requiring only two standards and relying on linearisation of the standard curve (fig. 4) was tested. Good correlation of assay results with those obtained using a full standard curve indicated the basic feasibility of this approach, but it was not an aim of these studies to perform full validation (precision, etc.) of the stat assay. In clinical application of any such method, the inclusion of qualitycontrol specimens in each assay run would be necessary, in accord with normal practice, as a confirmation of accuracy (8).

The digoxin FIA employs stable, non-radioactive reagents and may be performed using a simple filter fluorimeter. Using the stat procedure, a result for an urgent specimen could be obtained within about $1 \mathrm{~h}$. The assay requires a relatively large sample volume which could be a disadvantage in some circumstances. However, it was found that the majority of specimens submitted to the Hospital laboratory had a volume greater than $1 \mathrm{ml}$ and were thèrefore suitable for duplicate determination by FIA. Although the FIA correlated acceptably with two established RIA methods, the cross-reactivity of canrenone and canrenoate would suggest that in its present form it is unsuitable for assay of specimens from patients receiving spironolactone as well as digoxin. A similar problem in heterogeneous EIA was overcome by a change to a more specific antiserum reagent (12) and this would presumably also be effective in the FIA system.

\section{Acknowledgements}

M. H. H. Al-Hakiem gratefully acknowledges support from the Ministry of Higher Education and Scientific Research, Bagdad, and the University of Basrah, College of Medicine, Basrah, Iraq.

We thank the staff of the Routine Laboratory, Department of Chemical Pathology, St. Bartholomew's Hospital, who provided patients' specimens and results of digoxin determinations by charcoal-separation RIA.

\section{References}

1. Anon (1978) Amer. J. Hosp. Pharm. 35, 1495-1507.

2. Smith, T. W., Butler, V. P. \& Haber, E. (1969) N. Engl. J. Med. $281,1212-1216$.

3. Beller, G. A., Smith, T. W., Abelmann, W. H., Haber, E. \& Hodd, W. B. (1971) N. Engl. J. Med. 284, 989-997.
4. Smith, T. W. \& Haber, E. (1973) Pharmacol. Rev. 25, 219-228.

S. Ingelfinger, J. A. \& Goldman, P. (1976) N. Engl. J. Med. $294,867-870$. 
6. Drost, H., Plomp, Th. A., Teunissen, A. J., Maas, A. H. J. \& Maes, R. A. A. (1977) Clin. Chim. Acta 79, 557-567.

7. Sun, L. \& Spiehler, V. (1976) Clin. Chem. 22, 2029-2031.

8. Chen, I. W., Sperling, M., Volle, C. \& Maxon, H. R. (1978) Clin. Chem. 24, 1564-1567.

9. Chen, I. W., Sperling, M. \& Maxon, H. R. (1979) Clin. Chem. 25, 1841-1843.

10. Chang, J. J., Crowl, C. P. \& Schneider, R. S. (1975) Clin. Chem. 21, 967.

11. Oellerich, M. (1980) J. Clin. Chem. Clin. Biochem. 18, 197-208.

12. Borner, K. \& Rietbrock, N. (1978) J. Clin. Chem. Clin. Biochem. 16, 335-342.

13. O'Beirne, A. J. \& Cooper, H. R. (1979) J. Histochem. Cytochem. 27, 1148-1162.

14. Nargessi, R. D., Ackland, J., Hassan, M., Forrest, G. C., Smith, D. S. \& Landon, J. (1980) Clin. Chem. 26, $1701-1703$.

15. Pourfarzaneh, M., White, G. W., Landon, J. \& Smith, D. S. (1980) Clin. Chem. 26, 730-733.
16. Oliver, G. C., Parker, B. M., Brasfield, D. L. \& Parker, C. W. (1968) J. Clin. Invest. 47, 1035-1042.

17. Rodbard, D. (1978) Anal. Biochem. 90, 1-12.

18. Abraham, G. E. (1969) J. Clin. Endocrinol. 29, 866-870.

19. Smith, D. S., Pourfarzaneh, M. \& Kamel, R. S. (1980) Clin. Chem. 26, 1105 =1106.

20. Curry, R. E., Heitzman, H., Riege, D. H., Sweèt, R. V. \& Simonsen, M. G. (1979) Clin. Chem. 25, 1591-1595.

21. Ekeke, G. I. \& Exley, D. (197.8) in Enzyme Labelled Immunoassay of Hormones and Drugs (Pal, S.B., Ed.), pp. $195=205$, Walter de Gruyter, Berlin.

22. Lee, S. H. (1978) Amer. J. Clin. Pathōl. 70, 197-203.

23. Shechter, Y., Schlessinger, J., Jacobs, S., Chang, K.-J. \& Cuatrecasas, P. (1.978) Proc. Nat. Acad. Sçi. USA 75, 2135-2139.

24. Hassan, M., Landon, J. \& Smith, D. S. (1979) FEBS Lett. 103, 339-341.

Dr. D. S. Smith

Department of Chemical Pathology, St. Bartholomew's Hospital,

51 Bartholomew Close,

London EC1A 7HL, U.K. 